\title{
The differences between the antioxidant activity of vitamin products
}

\author{
Corresponding author: \\ Małgorzata Maciążek-Jurczyk \\ Department of Physical Pharmacy, \\ Faculty of Pharmaceutical Sciences, \\ Jagiellońska 4, 41-200 Sosnowiec, \\ e-mail: mmaciazek@sum.edu.pl
}

Medical Research Journal 2021;

Volume 6, Number 4, 281-287 10.5603/MRJ.a2021.0048

Copyright (C) 2021 Via Medica ISSN 2451-2591

e-ISSN 2451-4101

\begin{abstract}
Antioxidants are compounds naturally found in many products i.e. fruits, vegetables, and herbs. Antioxidants naturally occurring in plants include vitamins A, C, and E, polyphenols, and mineral compounds. These compounds are also found in many dietary supplements. This study aimed to determine the total antioxidant capacity (TAC) and total polyphenol content (TPC) of selected juices and dietary supplements. 1.1-diphenyl-2-picrylhydrazyl (DPPH) assay is a research method that allows antioxidant activity analysis. The TPC in test samples was measured by the Folin-Ciocalteu method.

The study showed that all selected for the analysis products have antioxidant properties. The values of TAC corresponded to TPC with 0.94 (juices) and 0.98 (diet supplements) correlation coefficients. The highest value of TAC was obtained for juice consisting of apples, beets, cherries, and the lowest for juice containing only carrots and products containing vitamin C composition.

The tested juices have higher values of TAC compared to dietary supplements, and therefore juices should be the basic prevention of civilization diseases.

Key words: antioxidants, civilization diseases, spectroscopy
\end{abstract}

Med Res J 2021; 6 (4): 281-287

\section{Introduction}

People often use vitamin products/dietary supplements available in pharmacies or grocery stores, which, in their opinion, can improve health [1]. Vitamin products/dietary supplements are not medicines. They are treated as food products that only supplement the human diet with elements that should be delivered in meals. For this reason, they are not subject to numerous and long research processes that each drug must undergo successfully [2]. One of the key functions of vitamin products is the supply of antioxidants [3]. Antioxidants are a naturally occurring group of chemical compounds that neutralize the negative effects of free radicals (FR) and remove their excess from the body. Endogenous antioxidants are found in every human body. These include enzymes with antioxidant activity, such as superoxide dismutase, as well as non-enzymatic factors such as melanin, glutathione, or albumin. The exogenous antioxidants that can be found in dietary supplements/vitamin products include, for example, vitamins, micro- and macro-elements, flavonoids, or carotenes [1-4].
Juices are rich in vitamins, mineral salts, and food acids. However, some technological processes used in the production and processing of juices may affect their antioxidant properties $[5,6]$.

The main goal of this work was to determine the total antioxidant capacity (TAC), the total content of polyphenolic compounds (TPC), and relationships between them in vitamin products/dietary supplements using UV-Vis spectroscopy.

\section{Material and methods}

\section{Material}

1.1-diphenyl-2-picrylhydrazyl (DPPH, $\mathrm{C}_{18} \mathrm{H}_{12} \mathrm{~N}_{5} \mathrm{O}_{6}$ ), Trolox $\left(T, \mathrm{C}_{14} \mathrm{H}_{18} \mathrm{O}_{4}\right)$, and ascorbic acid $\left(A A, \mathrm{C}_{6} \mathrm{H}_{8} \mathrm{O}_{6}\right)$ were obtained from Sigma-Aldrich, USA while ethyl alcohol $\left(\mathrm{C}_{2} \mathrm{H}_{5} \mathrm{OH}\right)$ and sodium carbonate $\left(\mathrm{Na}_{2} \mathrm{CO}_{3}\right)$ were sourced from Chempur, Poland. Gallic acid (GA, $\mathrm{C}_{7} \mathrm{H}_{6} \mathrm{O}_{5}$ ) and Folin-Ciocalteu reagent (FCR) were purchased from Merck, Germany, and POCH S.A., Poland, respectively. All chemicals and solvents were 
Table 1. Characteristics of juices selected for analysis

\begin{tabular}{|c|c|}
\hline Designation & Ingredients \\
\hline S1 & Apple (38.4 \%), banana (20\%) and spinach (20\%) purees, apple (20\%) and lemon (1.6\%) juices, vitamin C \\
\hline S2 & $\begin{array}{l}\text { Juices from concentrated juices and purees from carrots (35\%), apples ( } 21 \%) \text { and mangoes }(4 \%) \text {, water, sugar, } \\
\text { acidity regulators - citric and malic acid, vitamin C, flax seed extract (Linum ussitatisimum L) (0.2\%), aroma }\end{array}$ \\
\hline S3 & Carrot $(55 \%)$, tomato $(30 \%)$ and beetroot $(5 \%)$ juices, celery $(8 \%)$ and cucumber $(2 \%)$ purees, salt, vitamin C \\
\hline S4 & Orange juice, vitamin $\mathrm{C}$ \\
\hline S5 & Directly pressed apple (89.8\%) and blackcurrant (10\%) juices, lovage extract $(0.2 \%)$ \\
\hline S6 & Carrot juice (100\%), vitamin C \\
\hline$S 7$ & $\begin{array}{l}\text { Apple puree and juice }(48 \%) \text {, beet }(25 \%) \text {, cherry }(10 \%) \text {, chokeberry }(10 \%) \text { juices, banana puree }(4 \%) \text {, water, flax } \\
(1 \%) \text {, ginger }(0.1 \%)\end{array}$ \\
\hline S8 & $\begin{array}{l}\text { Juices from concentrated juices and purees from apples }(72.2 \%) \text {, pineapples }(10.2 \%) \text {, oranges }(6 \%) \text {, mango } \\
(3.3 \%) \text {, carrots, bananas, grapes }(1.3 \%) \text {, peaches }(1.3 \%) \text {, passion flower, lime }(0.4 \%) \text {, lychee, guava, cactus, kiwi } \\
(0.3 \%) \text {, papaya, vitamins A, D, E, C, B6, B12, thiamine, riboflavin, niacin, folic acid, biotin, pantothenic acid }\end{array}$ \\
\hline S9 & $\begin{array}{l}\text { Water, puree from peaches (20\%), carrots (19\%) and apples (13\%), sugar, acidity regulator — citric acid, vitamin } \\
\text { C and E, aroma }\end{array}$ \\
\hline$S 10$ & Apple (90\%) and chokeberry (10\%) juices \\
\hline
\end{tabular}

of analytical grade and used without further purification. Spectrophotometric analysis of 10 samples of juice and dietary supplements was performed. The solutions of diet supplements have been obtained by dissolving one tablet of each sample in $10 \mathrm{~mL}$ of ethanol. The designation and ingredients of samples are collected in Tables 1 and 2.

\section{Methods}

In order to study the antioxidant activity, the spectrophotometric method was used. DPPH (1.1-diphenyl-2-picrylhydrazyl) assay is a research technique that allows antioxidant activity analyses using the source of FR DPPH. Studies with the use of DPPH as the reference radical were carried out according to the modified protocol of Blois et al. [7]. The absorbance measurements of samples at room temperature using spectrophotometer JASCO V-760 (correcting the error of apparatus for wavelength and photometric is equal to $\pm 0.3 \mathrm{~nm}$ and \pm 0.002 Abs. at $0.5 \mathrm{Abs}$.). For the measurement standards, quartz cuvettes were used. To determine the antioxidant activity (TAC) and total content of polyphenolic compounds (TPC), the absorbance of the tested samples was measured at $\lambda 518 \mathrm{~nm}$ and $\lambda 765 \mathrm{~nm}$, respectively. A solution of DPPH at $138 \mu \mathrm{mol} \mathrm{dm}{ }^{-3}$ concentration in $96 \%$ ethanol was used. For Inhibition level, \% (I\%) and TAC studies as reference antioxidants, Trolox (TEAC, Trolox Equivalent Antioxidant Capacity) at 0.00125-0.0275 mg concentrations and ascorbic acid (AAEAC, Ascorbic Acid Equivalent Antioxidant Capacity) at 0.00148-0.0148 mg concentrations were used. TPC analysis, gallic acid (GAEAC, Gallic Acid Equivalent Antioxidant Capacity) at $0.000408-0.0048 \mathrm{mg}$ concentration was used.
Antioxidant activity, i.e. the percent inhibition of DPPH radical absorbance was calculated using the following equation [8].

Inhibition level, $\%=(A 0-A / A 0) \times 100(1)$ where:

$\mathrm{A}_{0}, \mathrm{~A}$ - absorbance of DPPH radical at $\lambda 518 \mathrm{~nm}$ (control sample), without and in the presence of TEAC, AAEAC, and GAEAC.

Based on the obtained (I\%) results, a linear relationship between the percent inhibition of DPPH (I\%) and the number of reference moles of TEAC [9] and AAEAC [10] antioxidants was determined (data not shown) and the regression equations were assessed as $\mathrm{y}_{\text {TEAC }}=795.67 \mathrm{x}-1.3064$ and $\mathrm{y}_{\text {AAEAC }}=1059.3 \mathrm{x}-1.4831$, where: $y$ is the $1 \%$ and $x$ is the volume of the sample in $\mathrm{mL}$. These equations were used to calculate the TAC of the studied juices and supplements diet in $\mathrm{mg} T$ or $A A$ per $250 \mathrm{~mL}$ juice (mg T/250 mL juice, mg AA/250 mL juice) or recommended daily dose of the products (mg T/recommended daily dose of the products, mg $\mathrm{AA} /$ recommended daily dose of the products). To evaluate the antioxidant activity of the tested products, up to $3 \mathrm{~mL}$ of DPPH solution at $138 \mu \mathrm{mol} / \mathrm{dm}^{3}$ concentration, juices and dietary supplements (from 0.003 to $0.03 \mathrm{~mL}$ ) were added, and the absorbance after $5 \mathrm{~min}$ of incubation was measured. Using Eq. (1), the I\% of DPPH was calculated. In the same manner, a linear relationship between the $1 \%$ of DPPH and the volume of the studied products $\mathrm{V} \mathrm{mL}$ was determined. Based on the regression equation of linear relationship of the $1 \%$ of the absorbance to the volume of sample, TAC expressed in the form of $T$ and $A A$ equivalents was determined $[9,10]$. The total polyphenol content in 
Table 2. Characteristics of diet supplements selected for the analysis

\begin{tabular}{|c|c|}
\hline Designation & Ingredients \\
\hline$P 1$ & $\begin{array}{l}\text { Magnesium }(56.25 \mathrm{mg}) \text {, calcium }(120 \mathrm{mg}) \text {, zinc }(1.5 \mathrm{mg}) \text {, selenium }(8.25 \mu \mathrm{g}) \text {, copper }(150 \mu \mathrm{g}) \text {, vitamin } \mathrm{C} \\
(80 \mathrm{mg}) \text {, niacin }(16 \mathrm{mg}) \text {, vitamin } \mathrm{E}(12 \mathrm{mg}) \text {, pantothenic acid }(6 \mathrm{mg}) \text {, vitamin B6 }(1.4 \mathrm{mg}) \text {, riboflavin }(1.4 \mathrm{mg}) \text {, } \\
\text { thiamine }(1.1 \mathrm{mg}) \text {, folic acid }(200 \mu \mathrm{g}) \text {, biotin }(50 \mu \mathrm{g}) \text {, coenzyme Q10 }(400 \mu \mathrm{g}) \text {, vitamin B12 }(2.5 \mu \mathrm{g})\end{array}$ \\
\hline$P 2$ & $\begin{array}{l}\text { Ginkgo biloba extract }(90 \mathrm{mg}) \text {, caffeine }(60 \mathrm{mg}) \text {, Panax ginseng extract }(50 \mathrm{mg}) \text {, Bacopa monnieri } L \text { extract } \\
\text { (36 mg) }\end{array}$ \\
\hline P3 & Vitamin C (100 mg) \\
\hline P4 & $\begin{array}{l}\text { Vitamin C (80 mg), niacin }(16 \mathrm{mg}) \text {, vitamin } \mathrm{E}(12 \mathrm{mg}) \text {, pantothenic acid }(6 \mathrm{mg}) \text {, vitamin B6 }(1.4 \mathrm{mg}) \text {, riboflavin } \\
(1.4 \mathrm{mg}) \text {, thiamine }(1.1 \mathrm{mg}) \text {, folic acid }(200 \mu \mathrm{g}) \text {, biotin }(50 \mu \mathrm{g}) \text {, vitamin B12 }(2.5 \mu \mathrm{g})\end{array}$ \\
\hline P5 & $\begin{array}{l}\text { Vitamin C }(80 \mathrm{mg}) \text {, zinc }(5 \mathrm{mg}) \text {, routine }(10 \mathrm{mg}) \text {, lemon juice concentrate }(50 \mathrm{mg}) \text {, honey powder }(50 \mathrm{mg}) \text {, } \\
\text { linden flower extract }(50 \mathrm{mg})\end{array}$ \\
\hline P6 & $\begin{array}{l}\text { Vitamin A }(800 \mu \mathrm{g}) \text {, vitamin B1 }(1.1 \mathrm{mg}) \text {, vitamin B2 }(1.4 \mathrm{mg}) \text {, vitamin B6 }(1.4 \mathrm{mg}) \text {, vitamin B12 }(2.5 \mu \mathrm{g}) \text {, vitamin } \\
\mathrm{C}(80 \mathrm{mg}) \text {, vitamin D }(5 \mu \mathrm{g}) \text {, vitamin } \mathrm{E}(12 \mathrm{mg}) \text {, vitamin } \mathrm{K}(25 \mu \mathrm{g}) \text {, biotin }(50 \mu \mathrm{g}) \text {, folic acid }(400 \mu \mathrm{g}) \text {, pantothenic } \\
\text { acid }(6 \mathrm{mg}) \text {, niacin }(16 \mathrm{mg}) \text {, selenium }(30 \mu \mathrm{g}) \text {, molybdenum }(50 \mu \mathrm{g}) \text {, iodine }(100 \mu \mathrm{g}) \text {, chromium }(40 \mu \mathrm{g}) \text {, zinc } \\
\text { (10 mg), copper }(1 \mathrm{mg}) \text {, iron }(21 \mathrm{mg}) \text {, magnesium }(60 \mathrm{mg}) \text {, calcium (120 mg), manganese }(2 \mathrm{mg}) \text {, ginseng root } \\
\text { extract (100 mg) }\end{array}$ \\
\hline$P 7$ & $\begin{array}{l}\text { Vitamin } \mathrm{E}(12 \mathrm{mg}) \text {, vitamin } \mathrm{C}(80 \mathrm{mg}) \text {, thiamine }(1.1 \mathrm{mg}) \text {, riboflavin }(1.4 \mathrm{mg}) \text {, vitamin } \mathrm{B} 6(1.4 \mathrm{mg}) \text {, vitamin B12 } \\
(2.5 \mu \mathrm{g}) \text {, pantothenic acid }(6 \mathrm{mg})\end{array}$ \\
\hline P8 & Vitamin C (80 mg), zinc $(2 \mathrm{mg})$, selenium $(8 \mu \mathrm{g})$, rutoside $(25 \mathrm{mg})$ \\
\hline P9 & $\begin{array}{l}\text { Vitamin } \mathrm{C}(80 \mathrm{mg}) \text {, niacin }(16 \mathrm{mg}) \text {, vitamin } \mathrm{E}(12 \mathrm{mg}) \text {, pantothenic acid }(6 \mathrm{mg}) \text {, vitamin B6 }(1.4 \mathrm{mg}) \text {, riboflavin } \\
(1.4 \mathrm{mg}) \text {, thiamine }(1.4 \mathrm{mg}) \text {, folic acid }(1.1 \mathrm{mg}) \text {, biotin }(200 \mu \mathrm{g}) \text {, vitamin B12 }(50 \mu \mathrm{g}) \text {, taurine }(400 \mathrm{mg}) \text {, caffeine } \\
(200 \mathrm{mg}) \text {, inositol }(40 \mathrm{mg})\end{array}$ \\
\hline P10 & $\begin{array}{l}\text { Tri-color violet herb extract }(170 \mathrm{mg}) \text {, dandelion root extract }(80 \mathrm{mg}) \text {, green tea leaf extract }(10 \mathrm{mg}) \text {, Gymnema } \\
\text { sylvestre } L \text { extract }(50 \mathrm{mg}) \text {, turmeric rhizome extract }(80 \mathrm{mg}) \text {, extract of lemon balm herb }(15 \mathrm{mg}) \text {, zinc }(18 \mathrm{mg} \\
\text { EN), niacin }(1.6 \mathrm{mg}) \text {, vitamin B6 }\end{array}$ \\
\hline
\end{tabular}

juices and diet supplements was measured by the Folin-Ciocalteu spectrophotometric method described by Canas et al. [11]. To determine the TPC, GA aqueous solutions were prepared in concentrations from 0.05 to $1.00 \mathrm{mg} / \mathrm{mL}$. $3.16 \mathrm{~mL}$ of water and $200 \mathrm{~mL}$ of FCR were added to $40 \mu \mathrm{L}$ of each $\mathrm{GA}$ solution at the appropriate concentration. The mixture was incubated for $5 \mathrm{~min}$. Next $600 \mu \mathrm{L}$ of a saturated sodium carbonate solution was added and left in a water bath at $40^{\circ} \mathrm{C}$ for $30 \mathrm{~min}$. After this time the solution became intense blue, and the absorbance was measured at $\lambda 765 \mathrm{~nm}$ [12].

\section{Statistical analysis}

The presented data were expressed as mean values whereas errors were calculated as standard deviation. The measurements were performed in triplicate. In order to study the correlation between TPC polyphenol content in juice and diet supplements and the value of antioxidant capacity, correlation coefficients $(r)$ were calculated by the Pearson's test with a level of significance of $p=0.05$. In order to study the normality of the distribution, the Shapiro-Wilk test was used. Linear regression by fitting experimental data to the appropriate equations was analyzed using OriginPro version 8.5 SR1 software (Northampton, MA, USA). Statistical tests were carried out using Statistica 13 software (StatSoft Polska Sp. z o.o., Poland).

\section{Results}

\section{Antioxidant activity and total antioxidant capacity analysis}

To determine antioxidant activity and TAC of juices and dietary supplements, UV-Vis spectra of the DPPH radical solution were taken, without and in the presence of juices or dietary supplements (data not shown). The calibration curve, as well as the data for juices and dietary supplements equations, are collected in Tables 3 and 4.

It has been observed that the antioxidants contained in juices and dietary supplements have a very wide range of activity and effectively limit the amount of FR scavenged by vitamins (AA, Vitamin E). The highest value of antioxidant capacity was obtained for the S7 sample, which included: apples, beets, cherries, chokeberry, and bananas and TAC equals $87.40 \mathrm{mg}$ $\mathrm{T} / 250 \mathrm{~mL}$ and $45.91 \mathrm{mg} \mathrm{AA} / 250 \mathrm{~mL}$ (Tab. 3).

In the next stage of the study, dietary supplements were analyzed. All vitamin products have similar composition and values of antioxidant potential. While analyzing the ingredients of these products, it was observed that the highest value is characteristic for product P3, containing vitamin $\mathrm{C}$ in the amount of $100 \mathrm{mg}$ in one tablet (Tab. 4). $\mathrm{P} 2$ and P10 samples have the lowest total antioxi- 
Table 3. Linear regression equations, $R^{2}$ and total antioxidant capacity expressed as $T$ and $A A$ equivalents

\begin{tabular}{|c|c|c|c|c|}
\hline Juices & Linear regression equation & $\mathbf{R}^{2}$ & $\begin{array}{c}\text { TAC } \\
\mathrm{mg} \mathrm{T} / 250 \mathrm{ml}\end{array}$ & $\begin{array}{c}\text { TAC } \\
\mathrm{mg} \mathrm{AA} / 250 \mathrm{ml} \\
\pm \mathrm{SD}\end{array}$ \\
\hline S1 & $y=2107.93 x+6.71$ & 0.9801 & $66.00 \pm 0.61$ & $34.67 \pm 0.08$ \\
\hline S2 & $y=1677.82 x+2.12$ & 0.9967 & $52.53 \pm 0.47$ & $27.60 \pm 0.06$ \\
\hline S3 & $y=2691.37 x+14.40$ & 0.9796 & $84.36 \pm 0.80$ & $44.27 \pm 0.10$ \\
\hline S4 & $y=1454.02 x+7.55$ & 0.9824 & $45.52 \pm 0.43$ & $23.92 \pm 0.05$ \\
\hline S5 & $y=2603.28 x+10.42$ & 0.9936 & $81.51 \pm 0.68$ & $42.82 \pm 0.08$ \\
\hline S6 & $y=617.28 x+1.32$ & 0.9814 & $19.33 \pm 0.18$ & $10.15 \pm 0.02$ \\
\hline$S 7$ & $y=2791.45 x+15.88$ & 0.9845 & $87.40 \pm 0.85$ & $45.91 \pm 0.11$ \\
\hline S8 & $y=1057.10 x+6.98$ & 0.9829 & $33.10 \pm 0.32$ & $17.39 \pm 0.04$ \\
\hline$S 9$ & $y=1454.27 x+4.06$ & 0.9839 & $45.53 \pm 0.42$ & $23.92 \pm 0.05$ \\
\hline$S 10$ & $y=1883.54 x+24.49$ & 0.8661 & $58,97 \pm 0.62$ & $30.98 \pm 0.08$ \\
\hline
\end{tabular}

AA — ascorbic acid; SD — standard deviation; T — trolox; TAC — total antioxidant capacity

Table 4. Linear regression equations, $\mathrm{R}^{2}$ and total antioxidant capacity expressed as $\mathrm{T}$ and $\mathrm{AA}$ equivalents for diet supplements

\begin{tabular}{lcccc}
\hline $\begin{array}{l}\text { Diet } \\
\text { supplements }\end{array}$ & Linear regression equation & $\mathbf{R}^{2}$ & $\begin{array}{c}\text { TAC } \\
\text { mg T/recommended } \\
\text { daily dose } \\
\pm \text { SD }\end{array}$ & $\begin{array}{c}\text { TAC } \\
\text { mg AA/ } \\
\text { /recommended } \\
\text { daily dose } \pm \text { SD }\end{array}$ \\
\hline$P 1$ & $y=2561.93 x+2.63$ & 0.9960 & $80.21 \pm 0.72$ & $42.14 \pm 0.09$ \\
$P 2$ & $y=1414.17 x+1.67$ & 0.9918 & $44.28 \pm 0.40$ & $23.26 \pm 0.05$ \\
$P 3$ & $y=3005.11 x+3.50$ & 0.9865 & $94.09 \pm 0.84$ & $49.43 \pm 0.10$ \\
$P 4$ & $y=2153.70 x+2.74$ & 0.9898 & $67.43 \pm 0.61$ & $35.42 \pm 0.08$ \\
$P 5$ & $y=2777.12 x+8.67$ & 0.9891 & $86.95 \pm 0.80$ & $45.68 \pm 0.10$ \\
$P 6$ & $y=1641.47 x+1.11$ & 0.9912 & $51.39 \pm 0.46$ & $27.00 \pm 0.06$ \\
$P 7$ & $y=2448.81 x-2.59$ & 0.9857 & $76.67 \pm 0.66$ & $40.28 \pm 0.08$ \\
$P 8$ & $y=2602.48 x-3.19$ & 0.9976 & $81.48 \pm 0.70$ & $42.80 \pm 0.09$ \\
$P 9$ & $y=1225.26 x-2.09$ & 0.9911 & $38.36 \pm 0.33$ & $20.15 \pm 0.04$ \\
$P 10$ & $y=593.83 x+1.35$ & 0.9861 & $18.29 \pm 0.17$ & $9.77 \pm 0.02$
\end{tabular}

AA — ascorbic acid; SD — standard deviation; T — trolox; TAC — total antioxidant capacity

dant activity. Their TAC parameters were equal to 44.28 and $18.59 \mathrm{mg} \mathrm{T} /$ recommended daily dose and 23.26 and $9.77 \mathrm{mg} \mathrm{AA} /$ recommended daily dose, respectively (Tab. 4).

\section{Total polyphenol content analysis}

Using the equation of the GA calibration curve, the TPC was calculated using the Folin-Ciocalteu method [13]. The obtained results were expressed in $\mathrm{mg}$ $\mathrm{GA} / 250 \mathrm{~mL}$ juice/recommended daily dose. Data are collected in Table 5.
The total amount of phenolic, measured by the Folin-Ciocalteu method, varied widely in the samples and ranged from 119.03 (S6) to 634.12 (S7) $\mathrm{mg} \mathrm{GA} / 250 \mathrm{~mL}$ and from 10.51 (P2) to 90.13 (P5), for juices and diet supplements, respectively (Tab. 5).

\section{The effect of polyphenols on total antioxidant capacity}

To examine the effect of polyphenols content in the analyzed juices and products (TPC) (Tab. 5) on their antioxidant activity expressed in the form of TAC (Tab. 4) 
Table 5. Total polyphenol content in tested juices (S1-S10) and diet supplements (P1-P10)

\begin{tabular}{|c|c|c|c|}
\hline Juices & TPC mg GA/250 $\mathrm{ml} \pm \mathrm{SD}$ & Diet supplements & TPC mg GA/recommended daily dose \pm SD \\
\hline S1 & $453.60 \pm 1.78$ & $P 1$ & $38.28 \pm 0.00$ \\
\hline S2 & $169.98 \pm 0.09$ & P2 & $10.51 \pm 0.07$ \\
\hline S3 & $388.29 \pm 0.00$ & P3 & $71.14 \pm 0.08$ \\
\hline S4 & $277.74 \pm 0.73$ & P4 & $63.87 \pm 0.00$ \\
\hline S5 & $449.16 \pm 0.18$ & P5 & $90.73 \pm 0.01$ \\
\hline S6 & $119.03 \pm 0.09$ & P6 & $56.86 \pm 0.15$ \\
\hline S7 & $634.12 \pm 0.55$ & $P 7$ & $75.07 \pm 0.08$ \\
\hline S8 & $157.70 \pm 0.91$ & P8 & $77.41 \pm 0.08$ \\
\hline s9 & $237.25 \pm 0.36$ & P9 & $33.40 \pm 0.01$ \\
\hline$S 10$ & $471.89 \pm 0.37$ & P10 & $11.94 \pm 0.02$ \\
\hline
\end{tabular}

GA — gallic acid; SD — standard deviation; TPC — total polyphenol content

of juices and dietary supplements, a Pearson's linear correlation analysis was performed between the TPC and the TAC expressed as T equivalents (TEAC) and AA (AAEAC). On the basis of the Shapiro-Wilk test, it was shown that the distribution was normal $(p>0.05$ : TAC for juices $p=0.70$; TPC for juices $p=0.52$; TAC for diet supplements $p=0.46$; TPC for diet supplements $p=0.40$ ). An analysis of the TAC and TPC values indicates a correlation between these values, both for juices $(r=0.94, p<0.05)$ and diet supplements $(r=0.98$, $p<0.05)$. For the majority of juices and diet supplements products, the most pronounced antioxidant activity was connected with the most elevated content of total polyphenol.

\section{Discussion}

The development of industry, increasing the pace of life, or unhealthy diet intensify the production of FR [4]. To prevent their occurrence, a healthy lifestyle, avoiding stimulants, and a diet rich in antioxidants are recommended [3-5]. There are also dietary supplements or rich vitamin products available over the counter. They are intended to supplement deficiencies of vitamins and minerals. Considering the above, this study aimed to determine the TAC and TPC in juices and dietary supplements. Moreover, the correlation between the TAC and TPC values was established. Antioxidant activity analysis was based on DPPH assay, using DPPH • as the standard radical. Moon et al. estimated that up to $90 \%$ of all publications in this field report the use of DPPH assay [3]. Sirivibulkovit et al. [14] reported that there are also studies using DPPH assay, even as a quick test strip, whose effectiveness does not differ in a statistically significant way from a traditional measuring method. Using Eq. (1), DPPH• $1 \%$ in the presence of standard antioxidants ( $T$ and $A A$ ) was calculated in order to exhibit antioxidant properties of juices and dietary supplements [9, 10].

Both S3 and S5 samples included vitamin C, which was used in this study as a standard for a powerful antioxidant [15-17]. The common ingredient of S7 and S5 juices was apple juice, while S7 and S3 beet juice (Tab. 1). Interestingly, the presence of apple juice in both juices that showed a high ability to remove FR and in those with less antioxidant activity means that it most likely has no direct impact on the antioxidant potential. As indicated by Żukiewicz-Sobczak et al. [18], the antioxidant activity of pure apple juice is low. The high and similar antioxidant activity of S7 and S3 samples could have resulted from the presence of beetroot juice, while the similar antioxidant activity of S7 and S5 was caused by various factors. Probably in the case of the S5 sample, blackcurrant juice was responsible for it (Tab. 3). The high antioxidant activity of blackcurrant juice is associated with very large amounts of flavones and anthocyanins that it contains [19].

The lowest value of antioxidant capacity was recorded in the case of juice containing only carrot (S6) because its total antioxidant capacity TAC was $19.33 \mathrm{mg} \mathrm{T} / 250 \mathrm{~mL}$ and $10.15 \mathrm{mg} \mathrm{AA} / 250 \mathrm{~mL}$ (Tab. 3). According to the literature, carrot juice without additives in the form of other ingredients also showed the lowest values of antioxidant potential [20,21]. Embaby et al. (2019) showed that the addition of Peruvian smiley juice (Physalis peruviana L.) to carrot juice (Daucus carota L.) contributed to a very significant increase in its antioxidant activity, which increased in the mixture of juices (30\%, $40 \%$, and $50 \%$ ) smiley juice [22]. It was 
found that the addition of other juices and vitamins increases the antioxidant potential, which was observed after comparing the antioxidative potentials of S6, as well as S8, S2, and S3 juices. In the case of S8, the number of ingredients was very high, but the effects of their joint action are not known, since the TAC was only $33.10 \mathrm{mg} \mathrm{T} / 250 \mathrm{~mL}$ and $17.39 \mathrm{mg} \mathrm{AA} / 250 \mathrm{~mL}$ (Tab. 3). There is a risk that so many accumulated substances with different antioxidant activity, different chemical nature, different properties, and perhaps interactions may result in antagonistic interactions in their antioxidant activity. An analogous situation was described by Dong et al. who showed that mixing two different herbal products, but only in a strictly defined proportion, gives a beneficial antioxidant effect [23].

As Azeem et al. [24] demonstrated, 3 components of $\mathrm{S} 2$ juice may be responsible for greater than $\mathrm{S} 6$ and S8 samples antioxidant activity: mango juice, vitamin $\mathrm{C}$, and citric acid, whose antioxidant activity is slightly lower than that of ascorbic acid. In the case of orange juice additionally enriched with vitamin C (S4), indirect antioxidant activity was observed. Its antioxidant capacity, expressed by T equivalents as well as ascorbic acid, was about twice as low as for the most effective juice (S7) and more than twice as high as for the least active carrot juice (S6) (Tab. 3). This is probably due to the presence of orange and carrot juice and their content in individual fruits. These are vitamin $\mathrm{C}$ and $\beta$-carotene, respectively [25].

The main components of P2 were Gingko Biloba extract, caffeine, and Panax ginseng root extract (Tab. 2). Both ethanol and acetone extracts of G. Biloba show some antioxidant activity, similar to ginseng root extract or caffeine [26-28]. An interesting relationship was observed between products P4 and P9. P4 had over 1.5 times total antioxidant capacity $(67.43 \mathrm{mg}$ T/recommended daily dose) compared to P9 (38.36 mg $\mathrm{T} /$ recommended daily dose). A similar relationship is observed for TAC expressed with the equivalent of ascorbic acid (Tab. 4). Surprisingly, the differences in the ingredients of both products were minimal. Both contain vitamins $\mathrm{C}, \mathrm{E}, \mathrm{B} 2, \mathrm{~B} 6$, and pantothenic acid in identical amounts while product $\mathrm{P9}$ contained more folic acid, biotin, vitamin B12, and thiamine than P4. The P9 sample also contained taurine, caffeine, and inositol, which were not present in the P4 sample (Tab. 2). This may mean that the presence of ingredients in P9, and those absent in P4, may contribute to a decrease in the antioxidant activity of the product.

Among the tested juices, S7, S1, and S5 samples showed the highest content of polyphenols in $250 \mathrm{~mL}$. High content of polyphenols was also observed in the case of S3 juice. The smallest content of polyphenols was shown in S6 and S8 (Tab. 5). This observation means that the increase in polyphenol content is directly proportional to the increase in the antioxidant capacity of the tested juices (Tab. 3). The authors of other similar research papers have shown the same relationship in their studies [18, 29]. In addition, Michalak-Majewska et al. [29] report higher content of polyphenols in terms of gallic acid and anthocyanins in blackcurrant juice than in apple and orange juices. Compared to the tested juice samples, the number of phenolic compounds contained in dietary supplements is very small (Tab. 5). The richest in these compounds was in the P5 sample and the poorest in the P2 product. The results obtained for the P5 sample are probably due to the presence of a large amount of routine in its composition (Tab. 2). It is a flavonoid polyphenolic compound that has antioxidant activity, and, like vitamin C, an increase in its concentration correlates with an increase in antioxidant activity, as demonstrated by Šircelj et al. [30] who examined the leaves of Oxalis acetosella $\mathrm{L}$. There is evidence that natural mixtures of juices, fruit, or fruit and vegetable extracts are a better source of antioxidants than dietary supplements. Literature data confirm the high content of polyphenols in juices because they are compounds naturally occurring in fruits and vegetables [29].

The increase in total polyphenol content is associated with an increase in the total antioxidant capacity in both juices and vitamin products. High content of polyphenols (TPC) corresponds to a high antioxidant capacity (TAC) have also been conducted by several researchers [9, 12, 29]. Roblová et al. [12] showed that a correlation coefficient $r$ between the analyzed parameters equals 0.861 , and that correlation was considered as high.

\section{Conclusion}

All tested products have antioxidant properties; however, juices have higher antioxidant capacity values than the tested vitamin products (dietary supplements). The highest value of antioxidant capacity was obtained for juice consisting of apples, beets, cherries, chokeberry, and bananas, and the lowest for juice containing only carrots, probably because the antioxidant properties of carrot juice depend on the addition of other compounds, such as polyphenolic compounds, ascorbic acid, or minerals. The highest value of total antioxidant capacity (TAC) is characteristic for the products containing vitamin $\mathrm{C}$ in the amount of $100 \mathrm{mg}$ in one pill. A strong correlation between TAC and total polyphenol content (TPC) in analyzed juices $(r=0.94, p<0.05)$ and diet supplements $(r=0.98, p<0.05)$ was observed. The TPC of analyzed juices $(250 \mathrm{~mL})$ is much higher than the TPC obtained for diet supplements (recommended daily dose). Taking into account the results, it has been concluded that such studies are very important from the 
public-health point of view and that juices and supplements can prevent civilization diseases connected with the fluctuation of FR level.

Conflict of interest: None.

\section{Funding: This research was funded by Grant KNW- 2-O-25/N/9/N from the Medical University of Silesia, Poland.}

\section{References}

1. Maughan RJ, King DS, Lea T. Dietary supplements. J Sports Sci. 2004: 22(1): 95-113, doi: 10.1080/0264041031000140581, indexed in Pubmed: 14971436.

2. Bojarowicz H, Dźwigulska P. Suplementy diety. Część I. Suplementy diety a leki — porównanie wymagań prawnych. Hygeia Public Health. 2012; 47(4): 427-432.

3. Moon JK, Shibamoto T. Antioxidant assays for plant and food components. J Agric Food Chem. 2009; 57(5): 1655-1666, doi: 10.1021/ff803537k, indexed in Pubmed: 19182948.

4. Kehrer JP, Klotz LO. Free radicals and related reactive species as mediators of tissue injury and disease: implications for Health. Crit Rev Toxicol. 2015; 45(9): 765-798, doi: 10.3109/10408444.2015.1074159, indexed in Pubmed: 26610815.

5. Durazzo A, Lucarini M, Novellino E, et al. Fruit-based juices: focus on antioxidant properties - study approach and update. Phytother Res. 2019; 33(7): 1754-1769, doi: 10.1002/ptr.6380, indexed in Pubmed: 31155809 .

6. Mennah-Govela YA, Bornhorst GM. Fresh-squeezed orange juice properties before and during in vitro digestion as influenced by orange variety and processing method. J Food Sci. 2017; 82(10): 2438-2447, doi: 10.1111/1750-3841.13842, indexed in Pubmed: 28833183.

7. Blois MS. Antioxidant determinations by the use of a stable free radical. Nature. 1958; 181(4617): 1199-1200, doi: 10.1038/1811199a0.

8. Tripathi A, Tandon M, Chandekar A, et al. In vitro antioxidant and anthelmintic activity on luffa cylindrica leaf extracts. J Herbs Spices Med Plants. 2016; 22(4): 348-355, doi: 10.1080/10496475.2016.1224211.

9. Qazi SS, Li D, Briens C, et al. Antioxidant activity of the lignins derived from fluidized-bed fast pyrolysis. Molecules. 2017; 22(3): 372, doi: 10.3390/molecules22030372, indexed in Pubmed: 28257062.

10. Dawson P, Al-Jeddawi W, Rieck J. The effect of different freezing rates and long-term storage temperatures on the stability of sliced peaches. Int J Food Sci. 2020; 2020: 9178583, doi: 10.1155/2020/9178583, indexed in Pubmed: 33294431.

11. Canas S, Casanova V, Belchior AP. Antioxidant activity and phenolic content of Portuguese wine aged brandies. J Food Compost Anal. 2008; 21 (8): 626-633, doi: 10.1016/j.jfca.2008.07.001.

12. Roblová V, Bittová M, Kubáň $P$, et al. Capillary electrophoresis fingerprinting and spectrophotometric determination of antioxidant potential for classification of Mentha products. J Sep Sci. 2016; 39(14): 28622868, doi: 10.1002/jssc.201600235, indexed in Pubmed: 27306863.

13. Lobo V, Patil A, Phatak A et al. Free radicals, antioxidants and functional foods: Impact on human health. Pharmacogn Rev. 2010; 4(8): 118-126, doi: 10.4103/0973-7847.70902, indexed in Pubmed: 22228951.

14. Sirivibulkovit K, Nouanthavong S, Sameenoi Y. Paper-based DPPH assay for antioxidant activity analysis. Anal Sci. 2018; 34(7): 795-800, doi: 10.2116/analsci.18P014, indexed in Pubmed: 29998961.
15. Maggini S, Wenzlaff $S$, Hornig D. Essential role of vitamin $C$ and zinc in child immunity and health. J Int Med Res. 2010; 38(2): 386-414, doi: 10.1177/147323001003800203, indexed in Pubmed: 20515554.

16. Buřičová L, Réblová Z. Czech medicinal plants as possible sources of antioxidants. Czech J Food Sci. 2008; 26(2): 132-138, doi: 10.17221/2468-cjfs.

17. Bouamama S, Merzouk H, Medjdoub A, et al. Effects of exogenous vitamins $\mathrm{A}, \mathrm{C}$, and $\mathrm{E}$ and $\mathrm{NADH}$ supplementation on proliferation, cytokines release, and cell redox status of lymphocytes from healthy aged subjects. Appl Physiol Nutr Metab. 2017; 42(6): 579-587, doi: 10.1139/apnm-2016-0201, indexed in Pubmed: 28177713.

18. Żukiewicz-Sobczak W, Michalak-Majewska M, Kalbarczyk J. Pojemność antyoksydacyjna wybranych napojów owocowych. Bromat Chem Toksykol. 2009; 42(3): 910-915.

19. Archaina D, Leiva G, Salvatori D, et al. Physical and functional properties of spray-dried powders from blackcurrant juice and extracts obtained from the waste of juice processing. Food Sci Technol Int. 2018; 24(1): 78-86, doi: 10.1177/1082013217729601, indexed in Pubmed: 28899204.

20. Nadeem M, Ubaid N, Qureshi TM, et al. Effect of ultrasound and chemical treatment on total phenol, flavonoids and antioxidant properties on carrot-grape juice blend during storage. Ultrason Sonochem. 2018; 45: 1-6, doi: 10.1016/j.ultsonch.2018.02.034, indexed in Pubmed: 29705302.

21. Park SH, Park HJ, Kim JY, et al. Mixed seeds juice with high antioxidant capacity and digestive enzyme activity and its application. Food Sci Biotechnol. 2017; 26(1): 237-244, doi: 10.1007/s10068-017-0032-3, indexed in Pubmed: 30263534

22. Embaby HES, Mokhtar SM. Impact of adding goldenberry (Physalis peruviana L.) on some quality characteristics and bio-functional properties of pasteurized carrot (Daucus carota L.) nectar. J Food Sci Technol. 2019; 56(2): 966-975, doi: 10.1007/s13197-018-03563-y, indexed in Pubmed: 30906054

23. Dong TTX, Zhao KJ, Gao QT, et al. Chemical and biological assessment of a chinese herbal decoction containing Radix Astragali and Radix Angelicae Sinensis: determination of drug ratio in having optimized properties. J Agric Food Chem. 2006; 54(7): 2767-2774, doi: 10.1021/jf053163l, indexed in Pubmed: 16569074.

24. Azeem M, Mu TH, Zhang M. Effects of high hydrostatic pressure and soaking solution on proximate composition, polyphenols, anthocyanins, $\beta$-carotene, and antioxidant activity of white, orange, and purple fleshed sweet potato flour. Food Sci Technol Int. 2020; 26(5): 388-402, doi: 10.1177/1082013219892716, indexed in Pubmed: 31870191.

25. Abbey M, Noakes M, Nestel PJ. Dietary supplementation with orange and carrot juice in cigarette smokers lowers oxidation products in copper-oxidized low-density lipoproteins. J Am Diet Assoc. 1995; 95(6): 671-675, doi: 10.1016/S0002-8223(95)00183-2, indexed in Pubmed: 7759743

26. Das D, Sen S, Sen K. Caffeine and catechin towards prevention of drug induced oxidation of hemoglobin: a spectroscopic study. Spectrochim Acta A Mol Biomol Spectrosc. 2020; 232: 118167, doi: 10.1016/j. saa.2020.118167, indexed in Pubmed: 32106030.

27. Cho WCS, Chung WS, Lee SKW, et al. Ginsenoside Re of Panax ginseng possesses significant antioxidant and antihyperlipidemic efficacies in streptozotocin-induced diabetic rats. Eur $\mathrm{J}$ Pharmacol. 2006; 550(1-3): 173-179, doi: 10.1016/j.ejphar.2006.08.056, indexed in Pubmed: 17027742.

28. Piazza S, Pacchetti B, Fumagalli M, et al. Comparison of two Ginkgo biloba L. extracts on oxidative stress and inflammation markers in human endothelial cells. Mediators Inflamm. 2019; 2019: 6173893, doi: 10.1155/2019/6173893, indexed in Pubmed: 31341420.

29. Michalak-Majewska M, Żukiewicz-Sobczak W, Kalbarczyk J. Ocena składu i właściwości soków owocowych preferowanych przez konsumentów. Bromat Chem Toksykol. 2009; 42(3): 836-841.

30. Šircelj H, Mikulič-Petkovšek M, Batič F. Antioxidants in spring leaves of Oxalis acetosella L. Food Chem. 2010; 123(2): 351-357, doi: 10.1016/j. foodchem.2010.04.042. 